\title{
Intrathymic Plasmablasts Are Affected in Patients With Myasthenia Gravis With Active Disease
}

Yohei Yamamoto, MD, Naoko Matsui, MD, Akiyuki Uzawa, MD, Yukiko Ozawa, MD, Tetsuya Kanai, MD, Fumiko Oda, MD, Hiroyuki Kondo, PhD, Izumi Ohigashi, PhD, Hiromitsu Takizawa, MD, Kazuya Kondo, MD, Mikio Sugano, MD, Takashi Kitaichi, MD, Hiroki Hata, MD, Ryuji Kaji, MD, Satoshi Kuwabara, MD, Takashi Yamamura, MD, and Yuishin Izumi, MD

Neurol Neuroimmunol Neuroinflamm 2021;8:e1087. doi:10.1212/NXI.0000000000001087

\section{Abstract}

\section{Background and Objectives}

To investigate intrathymic B lymphopoiesis in patients with myasthenia gravis (MG) and explore thymus pathology associated with clinical impact.

\section{Methods}

Thymic lymphocytes from 15 young patients without MG, 22 adult patients without MG, 14 patients with MG without thymoma, and 11 patients with MG with thymoma were subjected to flow cytometry analysis of $\mathrm{T}$ follicular helper ( $\mathrm{Tfh}$ ), naive $\mathrm{B}$, memory $\mathrm{B}$, plasmablasts, $\mathrm{CD} 19^{+} \mathrm{B} 220^{\text {high }}$ thymic B cells, B-cell activating factor receptor, and C-X-C chemokine receptor 5 (CXCR5). Peripheral blood mononuclear cells of 16 healthy subjects and 21 untreated patients with MG were also analyzed. Immunologic values were compared, and correlations between relevant values and clinical parameters were evaluated.

\section{Results}

The frequencies of circulating and intrathymic plasmablasts were significantly higher in patients with MG than controls. On the other hand, the frequency of $\mathrm{CD} 19^{+} \mathrm{B} 220^{\text {high }}$ thymic B cells was not increased in MG thymus. We observed a significant increase in CXCR5 expression on plasmablasts in MG thymus and an increased frequency of intrathymic plasmablasts that was correlated with preoperative disease activity. The frequency of intrathymic Tfh cells was significantly lower in patients who received immunosuppressive (IS) therapy than those without IS therapy. However, there was no significant difference in the frequency of intrathymic plasmablasts irrespective of IS therapy.

\section{Discussion}

Our findings confirmed a correlation between increased frequency of intrathymic plasmablasts and disease activity before thymectomy. We postulate that activated intrathymic plasmablasts endow pathogenic capacity in MG.

\author{
Correspondence \\ Dr. Matsui \\ nmatsui1818@gmail.com
}




\section{Glossary}

$\mathbf{A C h R}=$ acetylcholine receptor; $\mathrm{ADL}=$ activities of daily living; BAFF-R = B-cell activating factor receptor; CXCR5 = C-X-C chemokine receptor 5; GC = germinal center; HS = healthy subjects; IS = immunosuppressive; MFI = mean fluorescence intensity; MG = myasthenia gravis; $\mathbf{P M B C}=$ peripheral blood mononuclear cell; $\mathbf{T f h}=\mathrm{T}$ follicular helper; $\mathbf{T F H}=$ thymic follicular hyperplasia; TNF $=$ tumor necrosis factor.

Myasthenia gravis (MG) is a $\mathrm{CD} 4^{+} \mathrm{T}$ cell-dependent autoimmune disease that is caused by autoantibodies directed against different components of the neuromuscular junction. ${ }^{1}$ The thymus is presumably related to the triggering of anti-acetylcholine receptor (AChR) autoimmunity in earlyonset MG or thymoma-associated $\mathrm{MG}^{2,3}$ The thymus is an organ that supports $\mathrm{T}$-cell differentiation, but it also contains B cells. Although CD $19^{+}$B $220^{\text {high }}$ thymic B cells in the mouse are known as a unique phenotype that endows potent tolerogenic features, little is known about $\mathrm{CD} 19^{+-}$ $\mathrm{B} 220^{\text {high }}$ thymic $\mathrm{B}$ cells in the human thymus. ${ }^{4}$ Most patients with early-onset MG present with morphologic changes referred to as germinal centers (GCs) in their hyperplastic thymus. ${ }^{2}$ Because similar GCs have been reported in inflamed tissues of other autoimmune diseases such as the meninges of secondary progressive multiple sclerosis, the thymus is considered the inflamed tissue in anti-AChR antibody-positive patients with MG. Several chemokines including CXCL13 are responsible for the migration of $\mathrm{B}$ cells in MG thymus. In addition, both CXCL13 and B-cell activating factor (BAFF) have an important role in the formation and maintenance of B-cell follicles. ${ }^{3}$ The ectopic GCs in the thymus of patients with MG appear to be associated with humoral immune response that results in interactions with $\mathrm{B}$ cells and helper $\mathrm{T}$ cells. ${ }^{3}$ Some B-cell subsets and $\mathrm{T}$ follicular helper $(\mathrm{Tfh})$ cells play an important role in MG.

Recent studies showed increased plasma cells in ocular MG or increased plasmablasts in patients with neuromyelitis optica, and activated B-cell subsets were presumably related to disease activity. ${ }^{5-9}$ Several groups reported that the frequencies of circulating Tfh cells were significantly elevated in some autoimmune diseases including $\mathrm{MG}^{10-12}$ The enhanced number or activation of Tfh cells potentially activates B cells for the production of autoantibodies. However, little is known about intrathymic B lymphopoiesis and humoral immune response in MG thymus.

Thymectomy is the standard treatment for patients with MG who have thymoma. On the other hand, recent studies showed the beneficial effects of thymectomy plus prednisolone vs prednisolone alone in cases without thymoma. ${ }^{13,14}$ The reason why thymectomy is an effective treatment for patients with MG needs further investigation. To address these issues, in this study, we examined the involvement of Tfh cells and B-cell subsets in the thymus as well as the periphery in patients with MG.

\section{Methods}

\section{Patients}

The demographic data and the clinical information for patients and controls are summarized in Table 1 . The diagnosis of MG was made on the basis of clinical features plus one or more than one of the following features: positive response to anticholinesterase injection, electrophysiologic signs of neuromuscular transmission defect, and the presence of antibodies against AChR or muscle-specific tyrosine kinase. ${ }^{1,15}$ All patients with MG were positive for anti-AChR antibody. Blood was sampled from 21 patients with $M G$ before any clinical treatments including immunosuppressive (IS) therapy and 16 age-matched healthy subjects (HS) without immunologic diseases. The 21 patients with MG consisted of 6 patients with ocular MG and 15 patients with generalized MG, according to clinical presentation at the time of blood sampling and follow-up. Thymuses were obtained during cardiac surgery of non-MG patients presenting with heart disease or during thymectomy of non-MG patients presenting with thymoma and AChR-positive patients with generalized MG. Non-MG patients were divided into 2 groups according to age at operation: young, age $<18$ years, and adult, age $\geq 18$ years. All patients in the non-MG group having thymoma were seronegative for anti-AChR antibody before thymectomy and did not develop MG later. Pathologic diagnosis was based on the analysis of hematoxylin-eosin-stained sections. The MG subgroup was pathologically confirmed as follows: involuted thymus ( $\mathrm{n}=$ $9)$, thymic follicular hyperplasia (TFH) $(\mathrm{n}=5)$, and thymoma $(\mathrm{n}=11)$. The thymuses were finally classified as follows: young non-MG $(n=15)$, adult non-MG $(n=22)$, nonthymoma MG (involuted thymus and TFH) MG ( $\mathrm{n}=$ $14)$, and thymoma MG ( $\mathrm{n}=11)$. In the thymuses with thymoma, non-neoplastic tissues adjacent to the thymoma were analyzed. Fifteen of the $25 \mathrm{MG}(+)$ patients enrolled in this study took corticosteroids or immunosuppressants before the thymectomy. We showed the WHO Classification for the thymoma MG group and details of IS therapy before thymectomy (eTable 2, links.lww.com/NXI/A599). We determined the sex, age, disease duration (time from symptom onset to blood or thymus sampling), anti-AChR antibody titer, MGFA clinical classification, and the MG activities of daily living (MG-ADL) score. MG was assessed on the basis of MGFA, MG-ADL score, and anti-AChR antibody titer at the time of blood sampling, before thymectomy, and 12 months after thymectomy (Table 1, eTable 2, links.lww.com/NXI/A599). 


\section{Standard Protocol Approvals, Registrations, and Patient Consents}

This study was approved by the Ethics Committee of Tokushima University Hospital and Chiba University Hospital. All subjects gave written informed consent for participation.

\section{Multicolor Flow Cytometry Analysis}

Peripheral blood mononuclear cells (PBMCs) were separated by centrifugation of blood samples on Ficoll-Hypaque (Axis-Shield PoC AS, Norway) after blood sampling. ${ }^{9}$ Thymic lymphocytes were mechanically disrupted by gentle scraping of fresh thymus. The cells were filtered through sterile gauze and washed with PBS by pipetting. ${ }^{6}$

PBMCs or thymic lymphocytes were incubated with specific antibodies. Stained samples were acquired on a FACSVerse flow cytometer (Becton Dickinson, Franklin Lakes, NJ), and data were analyzed using FlowJo software (Tree Star, Ashland, OR). Cells were analyzed after staining using forward-scatter and sidescatter signals to establish the thymic lymphocytes gate, exclude propidium iodide ${ }^{+}$dead cells, and define $\mathrm{T}$ cells or $\mathrm{B}$ cells. The following antibodies were used in this study: $\mathrm{mAbs}$ against $\mathrm{CD} 3$, CD4, CD19, CD38, CD45R/B220, CD185 (C-X-C chemokine receptor 5 [CXCR5]), CD279 (PD-1), CD278 (ICOS), and CD268 (BAFF-R) (BioLegend, San Diego, CA) and mAbs against CD27 and CD180 (BD Biosciences, San Jose, CA) (eTable 1, links.lww.com/NXI/A599). To evaluate the activated plasmablasts, mean fluorescence intensity (MFI) of CXCR5 and BAFF-R on the plasmablasts was measured.

\section{Data Analysis and Statistics}

Differences in the frequency of cell subsets and MFI were compared using the Student $t$ test between the 2 groups (PBMC: HS and MG) or analysis of variance among the 4 groups (thymus: young non-MG, adult non-MG, nonthymoma $\mathrm{MG}$, and thymoma MG). To examine the influence of IS therapy before thymectomy, the Student $t$ test was used to compare the percentage of cell subsets and MFI in patients with IS therapy (IS+) and those without IS therapy (IS-). Correlations between cell subsets and clinical parameters (ie, age, disease duration, antibody titer, and MG-ADL score) were assessed by analyzing Pearson correlation coefficients. $p$ Values $<0.05$ were considered statistically significant. The data were analyzed using GraphPad Prism 8.

\section{Data Availability}

The data set analyzed in the present study is found in the main text and the supplementary files, links.lww.com/NXI/A599.

\section{Results}

\section{Circulating Tfh Cells and B-Cell Subsets}

We analyzed Tfh and B-cell subpopulations in peripheral blood sampled from $16 \mathrm{HS}$ and 21 patients with MG before any clinical treatments including IS therapy. None of the 6 patients with ocular MG developed secondary generalization later. Tfh cells were determined as $\mathrm{CXCR5}^{+} \mathrm{PD}-1^{+}$or $\mathrm{CXCR}^{+} \mathrm{ICOS}^{+}$on $\mathrm{CD}^{+} \mathrm{CD}^{+}(\mathrm{Tfh})$ cells. We found no

Table 1 Samples and Demographic/Clinical Information

\begin{tabular}{|c|c|c|c|c|c|c|c|c|c|c|c|}
\hline & \multirow{2}{*}{$\frac{\text { Sex }}{\text { Female (\%) }}$} & \multirow{2}{*}{$\frac{\text { Age, } y}{\text { Mean } \pm \text { SD }}$} & \multirow{2}{*}{$\frac{\text { Duration, } y}{\text { Mean } \pm S D}$} & \multirow{2}{*}{$\frac{\text { Ab titer }}{\text { Mean } \pm S D}$} & \multicolumn{6}{|c|}{ MGFA clinical classification, $\mathbf{n}(\%)$} & \multirow{2}{*}{$\frac{\text { MG-ADL }}{\text { Mean } \pm \text { SD }}$} \\
\hline & & & & & 0 & 1 & $\|$ & III & IV & V & \\
\hline \multicolumn{12}{|l|}{ Thymus } \\
\hline \multicolumn{12}{|l|}{ MG $(-)(n=37)$} \\
\hline Young ( $n=15$ ) & 26 & $4 \pm 7$ & & & & & & & & & \\
\hline Adult $(n=22)$ & 59 & $45 \pm 18$ & & & & & & & & & \\
\hline No neoplasm $(n=10)$ & 40 & $34 \pm 16$ & & & & & & & & & \\
\hline Thymoma $(n=12)$ & 75 & $54 \pm 15$ & & & & & & & & & \\
\hline \multicolumn{12}{|l|}{ MG $(+)(n=25)$} \\
\hline Nonthymoma $(n=14)$ & 100 & $36 \pm 18$ & $2.1 \pm 2.2$ & $186 \pm 450$ & $0(0)$ & $3(21)$ & $7(50)$ & $4(29)$ & $0(0)$ & $0(0)$ & $4.7 \pm 3.3$ \\
\hline Involuted thymus $(\mathrm{n}=9)$ & 100 & $41 \pm 18$ & $1.4 \pm 0.9$ & $243 \pm 558$ & $0(0)$ & $2(22)$ & $4(45)$ & $3(33)$ & $0(0)$ & $0(0)$ & $3.8 \pm 3.7$ \\
\hline $\operatorname{TFH}(n=5)$ & 100 & $27 \pm 17$ & $3.3 \pm 3.4$ & $83 \pm 114$ & $0(0)$ & $1(20)$ & $3(60)$ & $1(20)$ & $0(0)$ & $0(0)$ & $6.4 \pm 2.0$ \\
\hline Thymoma $(n=11)$ & 72 & $52 \pm 10$ & $1.1 \pm 1.9$ & $51 \pm 87$ & $0(0)$ & $5(45)$ & $6(55)$ & $0(0)$ & $0(0)$ & $0(0)$ & $2.0 \pm 1.2$ \\
\hline \multicolumn{12}{|l|}{ Peripheral blood } \\
\hline Healthy subjects $(n=16)$ & 68 & $51 \pm 14$ & & & & & & & & & \\
\hline Untreated patients with MG $(n=21)$ & 76 & $52 \pm 18$ & $1.1 \pm 2.0$ & $280 \pm 650$ & $0(0)$ & $7(33)$ & $7(33)$ & $7(33)$ & $0(0)$ & $0(0)$ & $6.9 \pm 3.3$ \\
\hline
\end{tabular}

Abbreviations: $A C h R=$ anti-acetylcholine receptor antibody (normal $<0.2 \mathrm{nmol} / \mathrm{L}$ ); $\mathrm{ADL}=$ activities of daily living; age = age at thymectomy; duration = period between disease onset and thymectomy; MGFA = Myasthenia Gravis Foundation of America; TFH = thymic follicular hyperplasia. 
significant difference in the frequencies of PD- $1^{+}$and $\mathrm{ICOS}^{+} \mathrm{Tfh}$ cells between $\mathrm{HS}$ and patients with $\mathrm{MG}$ (Figure 1, A and B). The profiles of naive $\mathrm{B}$ cells, memory $\mathrm{B}$ cells, and plasmablasts were determined from the complex expression $\left(\mathrm{CD} 19^{+} \mathrm{CD} 27^{-}\right.$, $\mathrm{CD} 19^{+} \mathrm{CD} 27^{+}$, and $\left.\mathrm{CD} 19^{+} \mathrm{CD} 27^{+} \mathrm{CD} 38^{\text {high }} \mathrm{CD} 180^{-}\right)$after gating out $\mathrm{CD}^{+}$cells (Figure 1C). The frequencies of circulating naive $B$ cells, memory $B$ cells, and plasmablasts were significantly higher in patients with MG than HS (Figure 1, D-F); of these, the frequency of plasmablasts was higher in patients with generalized MG than HS (Figure 1G). The percentage of plasmablasts was elevated in patients with MG with a longer disease duration $\left(r^{2}=0.358, p=0.040\right)$ and a higher anti-AChR antibody titer $\left(r^{2}=0.622, p=0.0001\right)$, but there was no correlation between the percentage of plasmablasts and the MG-ADL score (Figure 1, H-J). However, the percentages of naive B cells and memory $\mathrm{B}$ cells were not correlated with any clinical parameters (data not shown). We also found no significant difference in the expression of BAFF-R or CXCR5 on plasmablasts between HS and patients with MG (data not shown).

\section{Intrathymic Tfh Cells and B-Cell Subsets}

There was no significant difference in the percentages of $\mathrm{CXCR}^{+} \mathrm{PD}-1^{+}$or $\mathrm{CXCR}^{+} \mathrm{ICOS}^{+}$on $\mathrm{CD}^{+} \mathrm{CD}^{+}$(Tfh) cells in the thymuses among the 4 groups (Figure 2, $\mathrm{A}$ and B). Thymic B cells were defined by $\mathrm{CD} 19^{+} \mathrm{B} 220^{\text {high }}$ cells (Figure 2C). The percentage of $\mathrm{CD} 19^{+} \mathrm{B} 220^{\text {high }}$ thymic $B$ cells was higher in the young non-MG group than the other 3 groups, but the difference was not significant (Figure 2D). In contrast, memory B cells showed higher frequencies in the nonthymoma MG group than the 2 nonMG groups. Memory B cells were also significantly elevated in the nonthymoma MG group relative to the thymoma MG group (Figure 2, E-G). Plasmablasts were significantly increased in the nonthymoma MG group compared with the 2 non-MG groups (young non-MG vs nonthymoma MG, $p<0.0001$; adult non-MG vs nonthymoma MG, $p<0.0001$ ) (Figures 2, E, H). Higher levels of BAFF-R on plasmablasts were noted in the MG groups, but there was no significant difference in the levels of BAFF-R on plasmablasts between the non-MG groups and the MG groups (Figure 2I). We also found a significantly high expression of CXCR5 on plasmablasts in the MG groups relative to the young or adult non-MG group (young non-MG vs nonthymoma MG, $p<0.05$; adult non-MG vs nonthymoma $M G, p<0.05$; young nonMG vs thymoma MG, $p<0.01$; adult non-MG vs thymoma MG, $p<0.01$ ) (Figure 2J). Thymic B cells, naive B cells, and plasmablasts did not show any correlation with age, whereas memory B cells increased with age $\left(r^{2}=0.322, p=\right.$ 0.001) (Figure 3, A-D).

The percentage of plasmablasts in MG thymus was significantly elevated in patients with higher disease activity $\left(r^{2}=\right.$ $0.330, p=0.003$ ) (Figure 3E). We found no correlation between the percentage of intrathymic plasmablasts and the percentage of circulating plasmablasts, disease duration, or anti-AChR antibody titer (data not shown).

\section{Influence of IS Therapy Before Thymectomy in MG Thymus}

To evaluate the alteration of Tfh cells and B-cell subsets due to IS therapy before thymectomy, we examined Tfh cells and B-cell subsets in MG thymus in the IS+ MG group and the IS- MG group. Fifteen of the 25 patients with MG were given IS therapy, as follows: 9 patients, corticosteroids; 4 patients, corticosteroids plus tacrolimus; 1 patient, corticosteroids plus ciclosporin; and 1 patient, tacrolimus (eTable 2, links.lww.com/NXI/A599).

Our data showed that the percentages of $\mathrm{PD}-1^{+} \mathrm{Tfh}$ and $\mathrm{ICOS}^{+} \mathrm{Tfh}$ cells in MG thymus were significantly lower in the IS + MG group than the IS- MG group (Figure 4, A-C). However, the percentages of B-cell subsets were not altered by IS therapy (Figure 4, D-G). The percentages of thymic PD-1 and ICOS cells were not correlated with any clinical parameters (data not shown).

\section{Discussion}

We found elevated frequencies of plasmablasts in patients with MG, and elevated frequencies of intrathymic plasmablasts were correlated with increased MG symptoms. We also found that circulating plasmablast levels were high in patients with a long disease duration and high anti-AChR antibody titer. The percentage of circulating plasmablasts was not correlated with disease severity but was significantly higher in patients with generalized MG than HS. In addition, CXCR5 expression on plasmablasts was increased in MG thymus, whereas it was unaltered in the blood of patients with MG. In light of these findings, we propose that the elevated plasmablast levels may be associated with the development of immune response in patients with MG, and intrathymic plasmablasts may play an important role in increasing the pathogenicity of MG.

The contribution of B-cell subsets to MG immunopathology has not been precisely defined. In this study, we showed a method for the standardization of immunophenotyping for B-cell subsets in human thymic lymphocytes. We detected $\mathrm{CD} 19^{+} \mathrm{B} 220^{\text {high }}$ thymic B cells in human thymus, but our results indicated no significant alterations in the population of $\mathrm{CD} 19^{+} \mathrm{B} 220^{\text {high }}$ thymic B cells in MG thymus. We also detected increased frequencies of conventional memory $B$ cells and plasmablasts in nonthymoma MG thymuses. Our results partly agree with a previous study showing an increased frequency of memory B cells in hyperplastic MG thymus. ${ }^{6}$ The origin of thymic $B$ cells, including $\mathrm{CD} 19^{+} \mathrm{B} 220^{\text {high }}$ thymic B cells, has been a subject of debate. One study suggested that most thymic B cells stem from immigration rather than intrathymic de novo generation, because of the paucity of B-cell precursors in the thymus. ${ }^{4}$ Molecules such as CXCL12, CXCL13, and CCL21 contribute to $\mathrm{MG}$ thymus pathology by recruiting peripheral $\mathrm{B}$ cells. ${ }^{3}$ Therefore, thymic B cells in MG thymus would be of extrathymic origin rather than intrathymic origin, and that may be a prerequisite condition for MG thymus. 


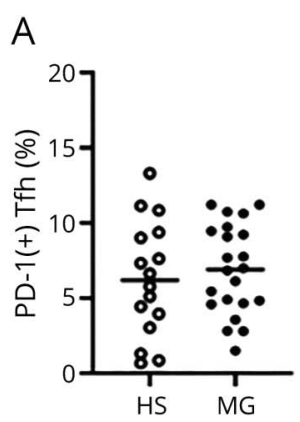

C.a HS

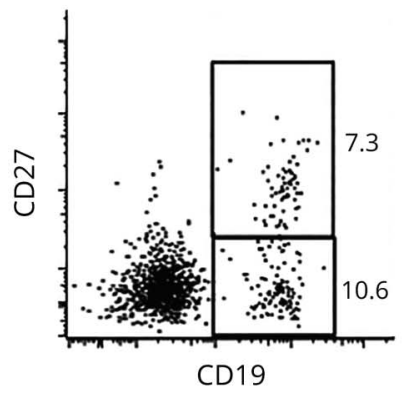

D

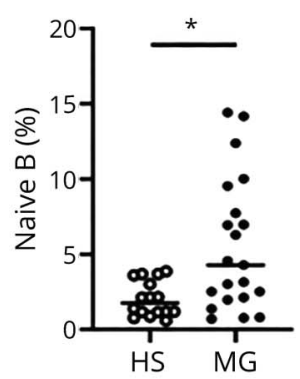

$\mathrm{H}$

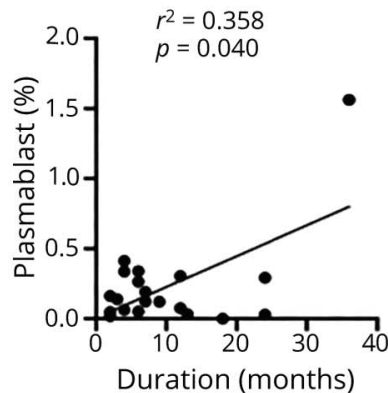

B

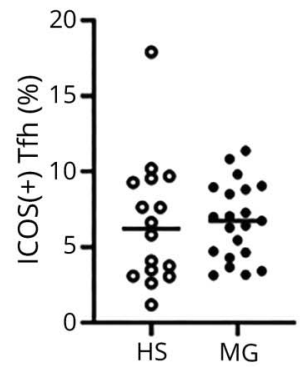

C.b MG
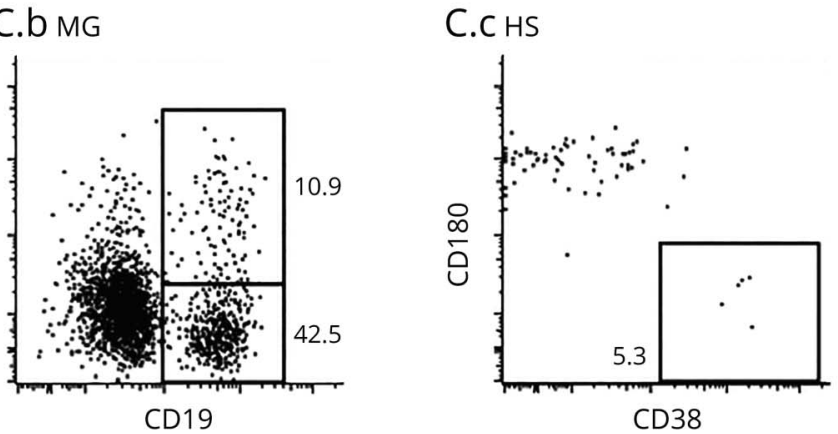

C.d MG

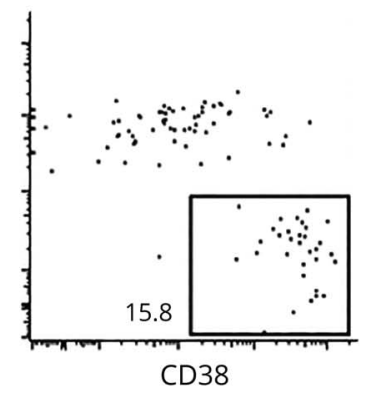

F
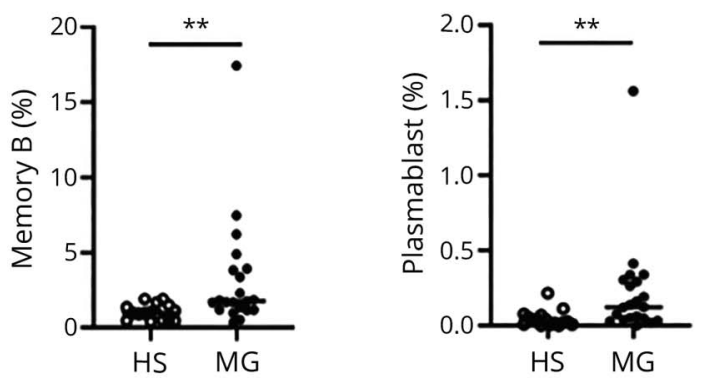

G

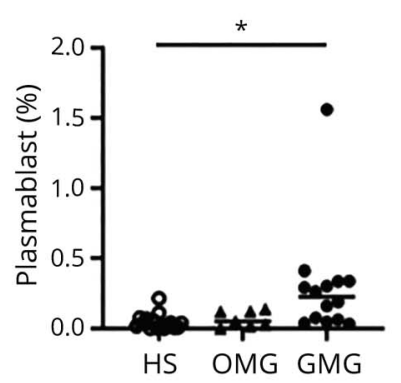

I

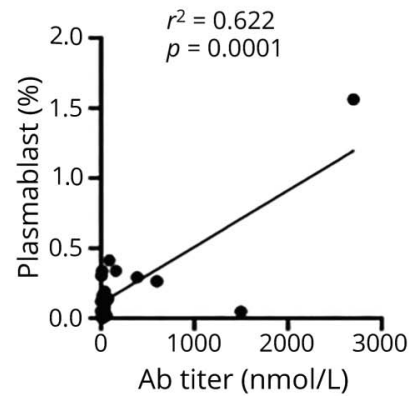

J

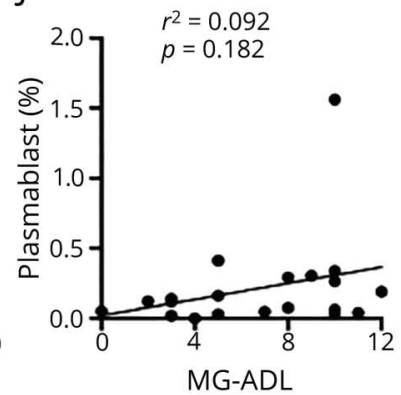

(A and B) Frequencies of PD- $1^{+}$Tfh and ICOS ${ }^{+}$Tfh cells in healthy subjects (HS) (open circles) and patients with MG (filled circles). (C) Representative dot plot profiles of CD19 and CD27 expression in CD3 ${ }^{-}$cells (left) and CD38 and CD180 expressions in CD3 ${ }^{-}$CD19 ${ }^{+}$CD27 $7^{+}$cells (right) in HS and patients with MG. Memory $B$ cells and naive B cells were detected as CD ${ }^{-}$CD $19^{+}$CD27 $7^{+}$cells and $\mathrm{CD}^{-} \mathrm{CD} 19^{+} \mathrm{CD} 27^{-}$cells, respectively. Plasmablasts were detected as $\mathrm{CD}^{+} 8^{+} \mathrm{CD} 180^{-}$cells in $\mathrm{CD}^{-} \mathrm{CD} 19^{+} \mathrm{CD} 27^{+}$cells. (D-F) Frequencies of naive B cells, memory B cells, and plasmablasts in HS (open circles) and patients with MG (filled circles). (G) Frequencies of plasmablasts in HS (open circles), patients with ocular MG (OMG) (filled triangles), and patients with generalized MG (GMG) (filled circles). ( $\mathrm{H}-\mathrm{J})$ Correlation analysis of frequency of plasmablasts and clinical parameters (duration, anti-acetylcholine receptor antibody titer, and MG-activities of daily living) in patients with MG. An unpaired $t$ test was used in A, B, D, E, and F. The Kruskal-Wallis test with Dunn multiple comparison test was used in $\mathrm{G}$. Correlations between the frequency of plasmablasts and clinical parameters were assessed using the Spearman rank correlation test in $\mathrm{H}$, I, and $\mathrm{J} .{ }^{*} p<0.05 ;{ }^{*} p<0.01$. MG = myasthenia gravis; $\mathrm{Tfh}=\mathrm{T}$ follicular helper.

The role of BAFF in MG remains one of the most controversial topics. BAFF, also known as B lymphocyte stimulator, is a member of the tumor necrosis factor (TNF) superfamily TNFSF 13, a potent survival factor for B cells. ${ }^{16,17}$ High BAFF levels were reported in the circulation in patients with $\mathrm{MG}{ }^{18}$ However, 1 study found no difference in the percentage of $\mathrm{B}$ cells that express the BAFF receptor (BAFF-R) between healthy controls and patients with MG. ${ }^{19}$ Another study 


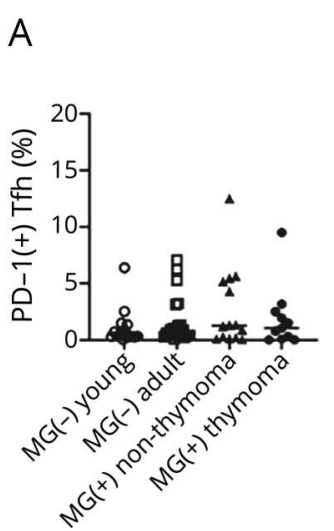

\section{B}

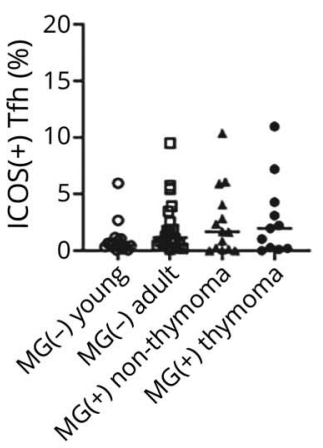

C.a MG(-) young

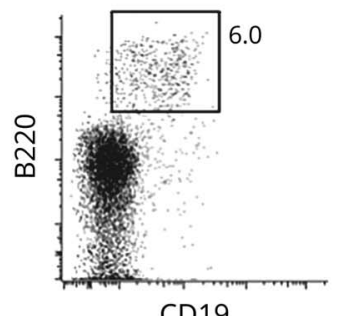

CD19
C.b MG(+) non-thymoma D

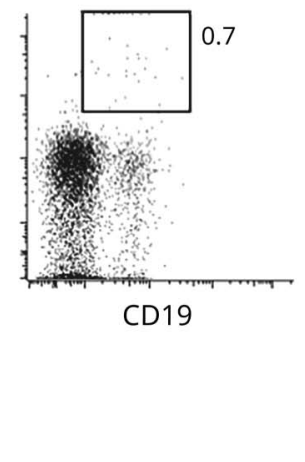

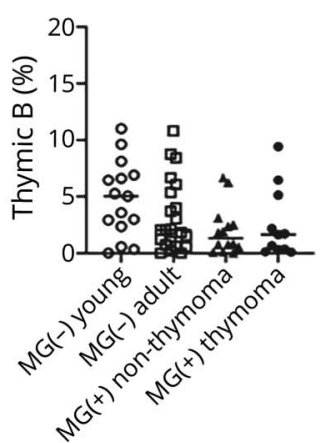

E.a MG(-) adult

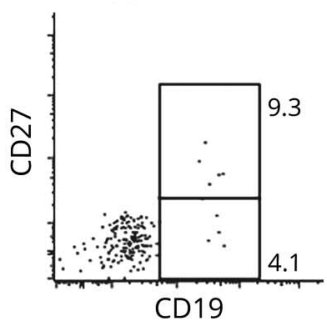

E.b $M G(+)$ non-thymoma

E.c MG(-) adult
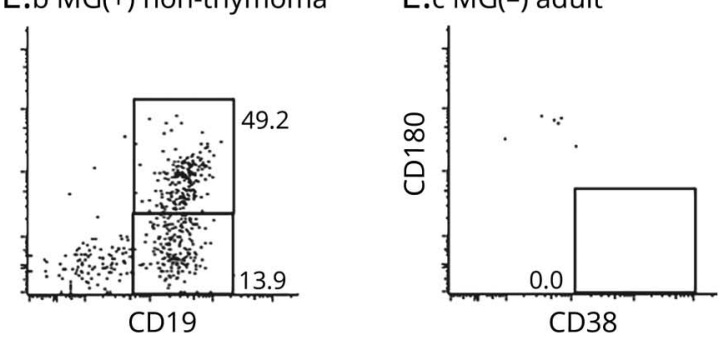

E.d MG(+) non-thymoma

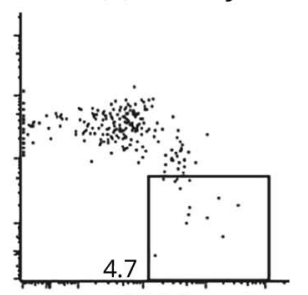

$\mathrm{CD} 38$
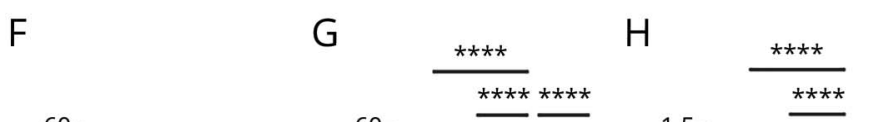

I
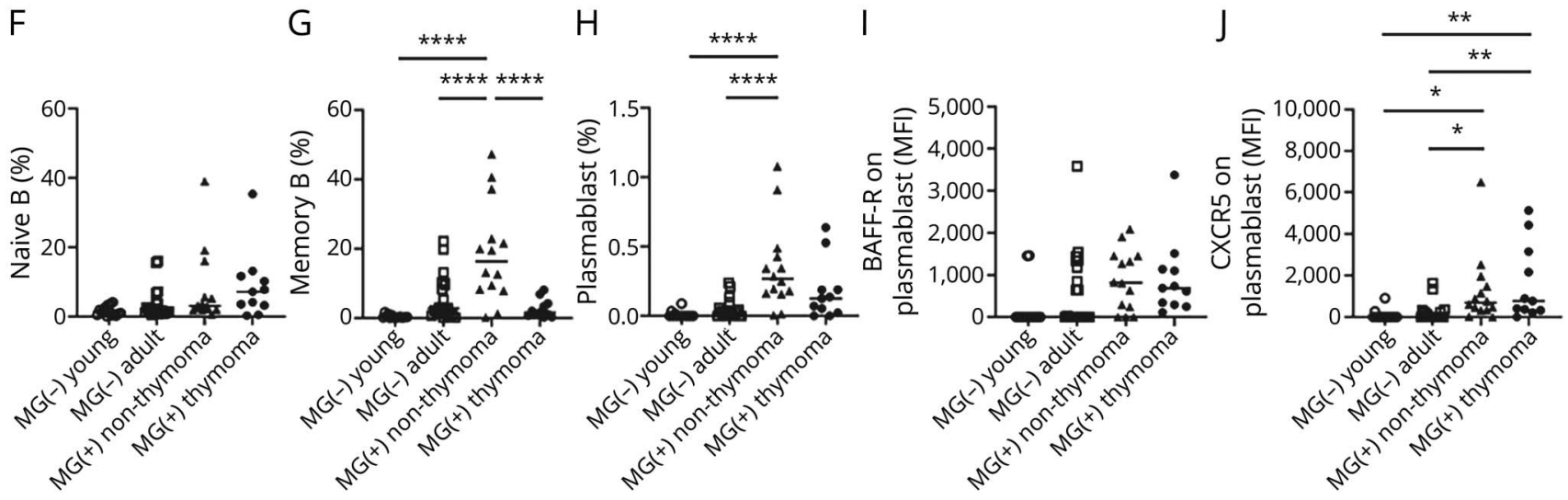

(A and B) Frequencies of PD- $1^{+}$Tfh cells and ICOS ${ }^{+}$Tfh cells in young non-MG patients (open circles), adult non-MG patients (open squares), patients with MG without thymoma (filled triangles), and patients with MG with thymoma (filled circles). (C) Representative dot plot profiles of CD19 and B220 expression in a young non-MG control (4-month-old female infant) and a patient with MG without thymoma (25-year-old woman) presenting with thymic hyperplasia. (D) Frequencies of CD19 ${ }^{+-}$ $B 220^{\text {high }}$ thymic B cells in young non-MG patients (open circles), adult non-MG patients (open squares), patients with MG without thymoma (filled triangles), and patients with MG with thymoma (filled circles). (E) Representative dot plot profiles of CD19 and CD27 expression in CD3- cells (left) and CD38 and CD180 expression in $\mathrm{CD}^{-} \mathrm{CD} 19^{+} \mathrm{CD} 27^{+}$cells (right) in an adult non-MG control (33-year-old man) and a patient with MG without thymoma (29-year-old woman) presenting with thymic hyperplasia. Memory B cells and naive B cells were detected as CD3 ${ }^{-} \mathrm{CD} 19^{+} \mathrm{CD} 27^{+}$cells and $\mathrm{CD} 3^{-} \mathrm{CD} 19^{+} \mathrm{CD} 27^{-}$cells, respectively. Plasmablasts were detected as $\mathrm{CD} 38^{+} \mathrm{CD} 180^{-}$cells in $\mathrm{CD}^{-} \mathrm{CD} 19^{+} \mathrm{CD} 27^{+}$cells. (F-H) Frequencies of naive B cells, memory B cells, and plasmablasts in young non-MG patients (open circles), adult nonMG patients (open squares), patients with MG without thymoma (filled triangles), and patients with MG with thymoma (filled circles). (I and J) Mean fluorescence intensity (MFI) of B-cell activating factor receptor and C-X-C chemokine receptor 5 on plasmablasts in young non-MG patients (open circles), adult non-MG patients (open squares), patients with MG without thymoma (filled triangles), and patients with MG with thymoma (filled circles). The Kruskal-Wallis test with Dunn multiple comparison test was used in A, B, D, F-J. * $p<0.05 ;{ }^{* \star} p<0.01$; ${ }^{* \star \star *} p<0.0001$. MG = myasthenia gravis; Tfh $=\mathrm{T}$ follicular helper.

indicated that macrophages expressing BAFF and BAFF-R were detected in GCs in hyperplastic MG thymus. ${ }^{20}$ In this study, we found no significant difference in the levels of BAFF-R on circulating plasmablasts between $H S$ and patients with MG (data not shown). In addition, increased levels of BAFF-R on plasmablasts were detected in hyperplastic MG thymus, but there was no significant difference in the levels of BAFF-R on plasmablasts between control thymuses and MG thymuses (eFigure 1, links.lww.
com/NXI/A597). These results suggest that BAFF may be partly involved in the formation of hyperplastic MG thymus but is not essential for the pathology in patients with MG.

CXCR5 is the chemokine receptor of CXCL13. CXCR5 is highly expressed on $\mathrm{B}$ cells and largely responsible for the B-cell partitioning into CXCL13-rich follicular areas in lymph nodes. $^{21,22}$ It was previously reported that CXCL13 is 
Figure 3 Correlation Analysis Between Intrathymic B-Cell Subsets and Clinical Profiles
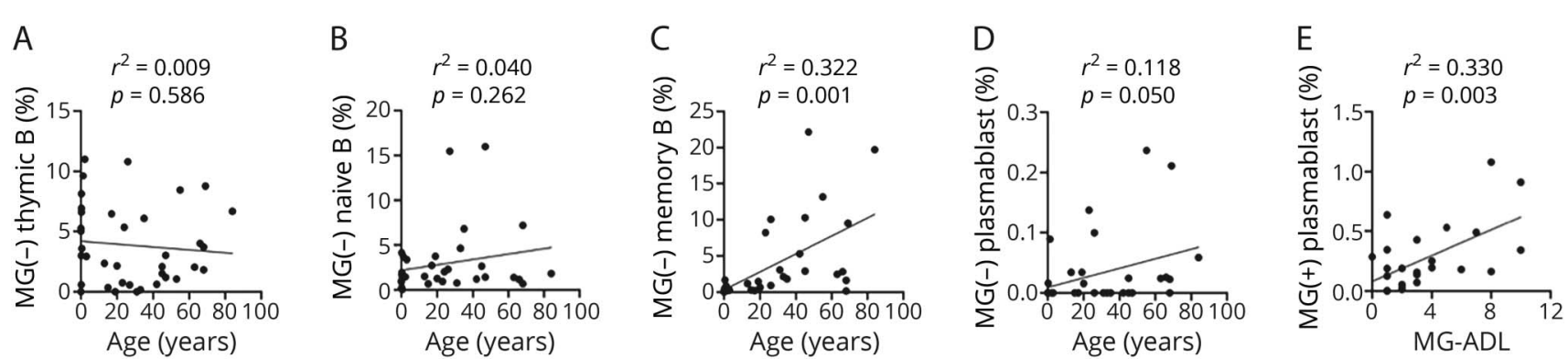

(A-D) Correlation analysis of frequencies of B-cell subsets and age in non-MG thymuses. (E) Correlation analysis of frequency of plasmablasts and the MG-activities of daily living score in MG thymuses. Correlations between frequency of each cell subset and clinical parameters were assessed using the Spearman rank correlation test. MG = myasthenia gravis.

involved in attracting peripheral B cells to MG thymus and in the organization of GCs. ${ }^{3,23}$ A previous report of a CXCL13 transgenic mouse showed that CXCL13 recruited B cells into the thymus under inflammatory conditions, and this mouse model mimics thymus pathology in human $\mathrm{MG}^{24}$ In this study, we found that the levels of CXCR5 on plasmablasts were significantly elevated in MG thymuses. Therefore, the high levels of CXCR5 on intrathymic plasmablasts may be associated with the recruitment of peripheral $B$ cells into $M G$ thymus and the formation of GCs.

Figure 4 Tfh Cells and B-Cell Subsets in MG Thymus With and Without IS Therapy

A.a MG IS+

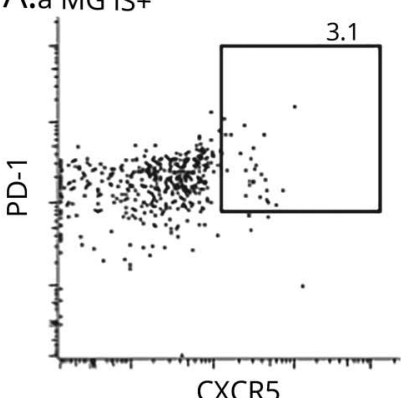

B

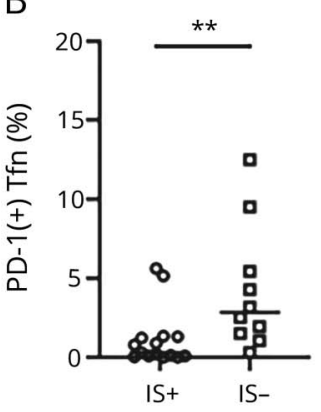

$\mathrm{E}$

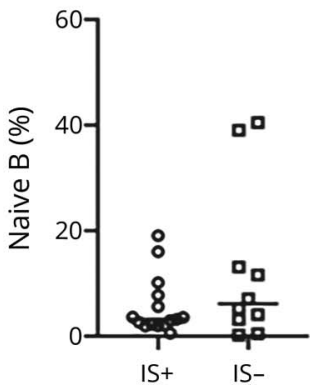

A.b MG IS-

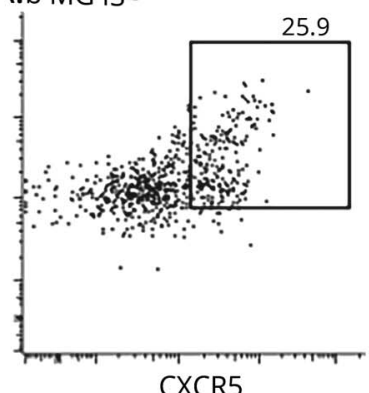

C

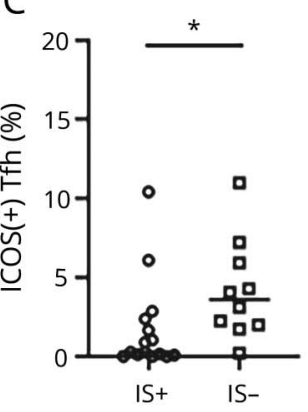

F

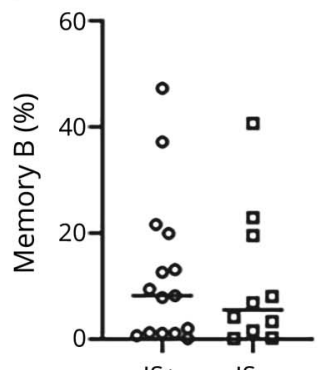

D

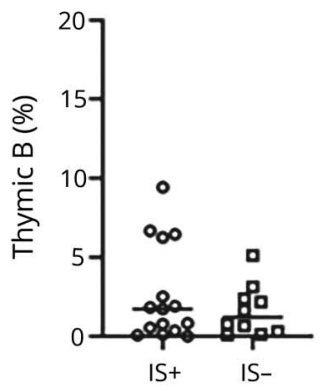

G

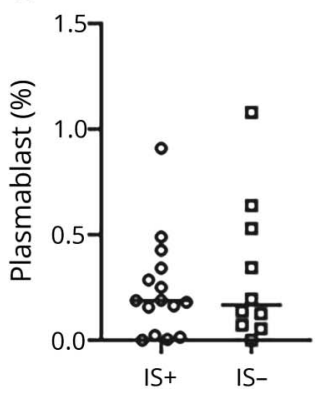

(A) Representative dot plot profiles of C-X-C chemokine receptor 5 and PD-1 expression in $\mathrm{CD3}^{+} \mathrm{CD}^{+}{ }^{+}\left(\mathrm{PD}-1^{+} \mathrm{Tfh}\right)$ cells in a patient with MG with IS therapy (IS+) (14-year-old girl) (left) and a patient with MG without IS therapy (IS-) (56-yearold woman) (right). Both patients with MG had thymic follicular hyperplasia. (B-G) Frequencies of PD- $1^{+}$Tfh Cells, ICOS ${ }^{+}$Tfh Cells, CD19 ${ }^{+}$B220 high thymic B Cells, naive B Cells, memory B Cells, and plasmablasts in patients with MG with IS therapy (IS+) (open circles) and those without IS therapy (IS-) (open squares). The unpaired $t$ test was used in B-G. ${ }^{*} p<0.05 ;{ }^{*} p<0.01$. IS = immunosuppressive; MG = myasthenia gravis; Tfh = T follicular helper. 
We detected no significant difference in the frequencies of circulating as well as intrathymic PD- $1^{+}$and $\mathrm{ICOS}^{+}$Tfh cells between controls and patients with MG. This contradicts the previous finding of the increased frequency of circulating $\mathrm{Tfh}$ cells in the blood of patients with MG or thymic Tfh cells in the thymus of patients with MG with thymoma. ${ }^{10,11,25,26} \mathrm{We}$ offer possible reasons for the discrepancy: a small number of subjects with MG were enrolled in our study; the enrolled subjects with MG were not severely affected compared with previous studies ${ }^{10,11}$; and previous studies have shown the expansion of the thymic Tfh cell population despite no immunomodulatory therapy before thymectomy. ${ }^{25,26}$

Corticosteroid treatment results in the reduction in the number and size of GCs. ${ }^{3}$ We showed that corticosteroid treatment significantly decreased $\mathrm{Tfh}$ cell proportions in MG thymus compared with untreated MG thymus. Our findings are in line with the previous report that IS therapy including corticosteroids downregulated circulating Tfh cell proportions in patients with systemic lupus erythematosus. ${ }^{27}$ GC response is impaired in the absence of $\mathrm{T}$ cell-expressed CXCR5 $^{28}$ These findings offer important insights into the mechanisms whereby IS therapy before thymectomy inhibits lymphoproliferative response leading to ectopic GCs.

Despite the MGTX study and its extension study, controversies surrounding therapeutic thymectomy have remained unaddressed. ${ }^{13,14}$ Our results offer important insight into the pathogenic role of the thymus, whereby intrathymic B lymphopoiesis increases the disease activity. Our results also suggest that the reduction of plasmablasts contributes to beneficial effects after thymectomy, even after corticosteroid treatment. However, our study has some limitations. The fact that 12 of the 14 patients in the nonthymoma MG group received IS therapy may influence the interpretation of intrathymic Tfh cells and B-cell subsets. In addition, the examination in the thymoma group was limited to nonneoplastic tissues surrounding the thymoma. This has prevented us from drawing solid conclusions on the role of thymectomy in some disease subtypes such as thymoma associated with MG. In conclusion, we speculate that the interactions of activated plasmablasts with Tfh cells contribute to B-cell recruitment and clinical presentation in MG thymus.

\section{Study Funding}

This research was supported by Japan Society for the Promotion of Science Grant-in-Aid for Research Activity start-up (Grant Number 19K23946) and Grant-in-Aid for Scientific Research C (Grant Number 20K0778400). This study was also supported by Health and Labor Sciences Research Grant on Intractable Diseases (Neuroimmunological Diseases) from the Ministry of Health, Labour and Welfare of Japan (20FC1030).

\section{Disclosure}

The authors report no disclosures relevant to the manuscript. Go to Neurology.org/NN for full disclosures.

\section{Publication History}

Received by Neurology: Neuroimmunology \& Neuroinflammation September 23, 2020. Accepted in final form August 4, 2021.

Appendix Authors

\begin{tabular}{lll}
\hline Name & Location & Contribution \\
\hline $\begin{array}{l}\text { Yohei } \\
\text { Yamamoto, }\end{array}$ & $\begin{array}{l}\text { Tokushima University, } \\
\text { Tokushima, Japan }\end{array}$ & $\begin{array}{l}\text { Major role in the acquisition } \\
\text { of data, analyzed the data, } \\
\text { and drafted and revised the } \\
\text { manuscript for intellectual } \\
\text { content }\end{array}$ \\
\hline $\begin{array}{l}\text { Naoko } \\
\text { Matsui, MD }\end{array}$ & $\begin{array}{l}\text { Tokushima University, } \\
\text { Tokushima, Japan }\end{array}$ & $\begin{array}{l}\text { Designed and conceptualized } \\
\text { the study, major role in the } \\
\text { acquisition of data, analyzed } \\
\text { and interpreted the data, and } \\
\text { drafted and revised the } \\
\text { manuscript for intellectual } \\
\text { content }\end{array}$ \\
\hline
\end{tabular}

\begin{tabular}{lll}
\hline Akiyuki & Chiba University, Chiba, & $\begin{array}{l}\text { Major role in the acquisition } \\
\text { of data and revised the } \\
\text { manuscript for intellectual } \\
\text { content }\end{array}$ \\
\hline
\end{tabular}

Yukiko Chiba University, Chiba, Major role in the acquisition of

\begin{tabular}{lll}
$\begin{array}{l}\text { Yukiko } \\
\text { Ozawa, MD }\end{array}$ & $\begin{array}{l}\text { Chiba University, Chiba, } \\
\text { Japan }\end{array}$ & $\begin{array}{l}\text { Major role in the acquisition of } \\
\text { data }\end{array}$ \\
\hline
\end{tabular}

Tetsuya Chiba University, Chiba, Major role in the acquisition of
Kanai, MD Japan data

\begin{tabular}{lll}
\hline $\begin{array}{l}\text { Fumiko } \\
\text { Oda, MD }\end{array}$ & $\begin{array}{l}\text { Chiba University, Chiba, } \\
\text { Japan }\end{array}$ & $\begin{array}{l}\text { Major role in the acquisition of } \\
\text { data }\end{array}$ \\
\hline $\begin{array}{l}\text { Hiroyuki } \\
\text { Kondo, PhD }\end{array}$ & $\begin{array}{l}\text { Tokushima University, } \\
\text { Tokushima, Japan }\end{array}$ & $\begin{array}{l}\text { Analyzed the data and revised } \\
\text { the manuscript for intellectual } \\
\text { content }\end{array}$ \\
\hline
\end{tabular}

Izumi Tokushima University, Analyzed the data and revised

\begin{tabular}{lll}
\hline Izumi & Tokushima University, & Analyzed the data and revised \\
Ohigashi, & Tokushima, Japan & the manuscript for intellectual
\end{tabular}

PhD content

\begin{tabular}{|c|c|c|}
\hline $\begin{array}{l}\text { Hiromitsu } \\
\text { Takizawa, } \\
\text { MD }\end{array}$ & $\begin{array}{l}\text { Tokushima University, } \\
\text { Tokushima, Japan }\end{array}$ & $\begin{array}{l}\text { Major role in the acquisition of } \\
\text { data }\end{array}$ \\
\hline $\begin{array}{l}\text { Kazuya } \\
\text { Kondo, MD }\end{array}$ & $\begin{array}{l}\text { Tokushima University, } \\
\text { Tokushima, Japan }\end{array}$ & $\begin{array}{l}\text { Major role in the acquisition of } \\
\text { data and revised the manuscript } \\
\text { for intellectual content }\end{array}$ \\
\hline $\begin{array}{l}\text { Mikio } \\
\text { Sugano, MD }\end{array}$ & $\begin{array}{l}\text { Tokushima University, } \\
\text { Tokushima, Japan }\end{array}$ & $\begin{array}{l}\text { Major role in the acquisition of } \\
\text { data }\end{array}$ \\
\hline $\begin{array}{l}\text { Takashi } \\
\text { Kitaichi, MD }\end{array}$ & $\begin{array}{l}\text { Tokushima University, } \\
\text { Tokushima, Japan }\end{array}$ & $\begin{array}{l}\text { Major role in the acquisition of } \\
\text { data }\end{array}$ \\
\hline $\begin{array}{l}\text { Hiroki Hata, } \\
\text { MD }\end{array}$ & $\begin{array}{l}\text { Tokushima University, } \\
\text { Tokushima, Japan }\end{array}$ & $\begin{array}{l}\text { Major role in the acquisition of } \\
\text { data }\end{array}$ \\
\hline $\begin{array}{l}\text { Ryuji Kaji, } \\
\text { MD }\end{array}$ & $\begin{array}{l}\text { National Hospital } \\
\text { Organization Utano } \\
\text { Hospital, Kyoto, Japan }\end{array}$ & $\begin{array}{l}\text { Major role in the acquisition of } \\
\text { data }\end{array}$ \\
\hline $\begin{array}{l}\text { Satoshi } \\
\text { Kuwabara, } \\
\text { MD }\end{array}$ & $\begin{array}{l}\text { Chiba University, Chiba, } \\
\text { Japan }\end{array}$ & $\begin{array}{l}\text { Major role in the acquisition of } \\
\text { data }\end{array}$ \\
\hline $\begin{array}{l}\text { Takashi } \\
\text { Yamamura, } \\
\text { MD }\end{array}$ & $\begin{array}{l}\text { National Center of } \\
\text { Neurology and Psychiatry } \\
\text { (NCNP), Tokyo, Japan }\end{array}$ & $\begin{array}{l}\text { Designed and conceptualized } \\
\text { the study and revised the } \\
\text { manuscript for intellectual } \\
\text { content }\end{array}$ \\
\hline $\begin{array}{l}\text { Yuishin } \\
\text { Izumi, MD }\end{array}$ & $\begin{array}{l}\text { Tokushima University, } \\
\text { Tokushima, Japan }\end{array}$ & $\begin{array}{l}\text { Major role in the acquisition of } \\
\text { data and revised the } \\
\text { manuscript for intellectual } \\
\text { content }\end{array}$ \\
\hline
\end{tabular}




\section{References}

1. Vincent A, Palace J, Hilton-Jones D. Myasthenia gravis. Lancet. 2001;357(9274); 2122-2128.

2. Marx A, Pfister F, Schalke B, Saruhan-Direskeneli G, Melms A, Ströbel P. The different roles of the thymus in the pathogenesis of the various myasthenia gravis subtypes. Autoimmune Rev. 2013(9);12:875-884.

3. Berrih-Aknin S, Ragheb S, Le Panse R, Lisak RP. Ectopic germinal centers, BAFF and anti-B-cell therapy in myasthenia gravis. Autoimmune Rev. 2013;12(9):885-893.

4. Yamano T, Nedjic J, Hinterberger M, et al. Thymic B cells are licensed to present self antigens for central $\mathrm{T}$ cell tolerance induction. Immunity. 2015;16(6):1048-1061.

5. Yin W, Allman W, Ouyang S, et al. The increased expression of CD21 on AchR specified B cells in patients with myasthenia gravis. J Neuroimmunol. 2013;256(1-2): 49-54.

6. Kohler S, Keil TO, Swierzy M, et al. Disturbed B cell subpopulations and increased plasma cells in myasthenia gravis patients. J Neuroimmunol. 2013;264(1-2):114-119.

7. Sun F, Ladha SS, Yang L, et al. Interleukin-10 producing-B cells and their association with responsiveness to rituximab in myasthenia gravis. Muscle Nerve. 2014;49(4): 487-494.

8. Guptill JT, Yi JS, Sanders DB, et al. Characterization of B cells in muscle-specific kinase antibody myasthenia gravis. Neurol Neuroimmunol Neuroinflamm. 2015;26(2):e77.

9. Chihara $\mathrm{N}$, Aranami $\mathrm{T}$, Sato $\mathrm{W}$, et al. Interleukin 6 signaling promotes anti-aquaporin 4 autoantibody production from plasmablasts in neuromyelitis optica. Proc Natl Acad Sci. 2011;108(9):3701-3706.

10. Luo C, Li Y, Liu W, et al. Expansion of circulating counterparts of follicular helper $\mathrm{T}$ cells in patients with myasthenia gravis. J Neuroimmunol. 2013;256(1-2):55-61.

11. Zhang CJ, Gong Y, Zhu W, et al. Augmentation of circulating follicular helper T cells and their impact on autoreactive B cells in myasthenia gravis. J Immunol. 2016;197(7): 2610-2617.

12. Le Coz C, Joublin A, Pasquali JL, Korganow AS, Dumortier H, Monneaux F. Circulating TFH subset distribution is strongly affected in lupus patients with an active disease. PLoS One. 2013;8(9):e75319.

13. Wolf GI, Kaminski HJ, Aban IB, et al. Randomized trial of thymectomy in myasthenia gravis. N Engl J Med. 2016;375(6):511-522.

14. Wolf GI, Kaminski HJ, Aban IB, et al. Long-term effect of thymectomy plus prednisone versus prednisone alone in patients with non-thymomatous myasthenia gravis: 2-year extension of the MGTX randomized trial. Lancet Neurol. 2019;18(3):259-268.
15. Jaretzki A III, Barohn RJ, Ernstoff RM, et al. Myasthenia gravis: recommendations for clinical research standards. Task force of the medical scientific advisory board of the myasthenia gravis foundation of America. Neurology. 2000;55(1):16-23.

16. Moore PA, Belvedere O, Orr A, et al. BlyS: member of the tumor necrosis factor family and B lymphocyte stimulator. Science. 1999;285(5425):260-263.

17. Schneider P, MacKay F, Steiner V, et al. BAFF, a novel ligand of the tumor necrosis factor family, stimulates B cell growth. J Exp Med. 1999;189(11):1747-1756.

18. Ragheb S, Lisak R, Lewis R, Van Stavern G, Gonzales F, Simon K. A potential role for B-cell activating factor in the pathogenesis of autoimmune myasthenia gravis. Arch Neurol. 2008;65(10):1358-1362.

19. Thangarajh M, Kisiswa L, Pirskanen R, Hillert J. The expression of BAFF-binding receptors is not altered in multiple sclerosis or myasthenia gravis. Scand J Immunol. 2007;65(5):461-466.

20. Thangarajh M, Masterman T, Helgeland L, et al. The thymus is source of B-cell-survival factors-APRIL and BAFF-in myasthenia gravis. J Neuroimmunol. 2006;178(1-2):161-166.

21. Legler DF, Loetscher M, Roos RC, Clark-Lewis I, Baggiolini M, Mooser B. B cellattracting chemokine 1, a human CXC chemokine expressed in lymphoid tissues, selectively attracts B lymphocytes via BLR1/CXCR5. J Exp Med. 1998;187(4): 655-660.

22. Ansel KM, Ngo VN, Hyman PL, et al. A chemokine-driven positive feedback loop organizes lymphoid follicles. Nature. 2000;406(6793):309-314.

23. Meraouna A, Cizeron-Clairac G, Panse RL, et al. The chemokine CXCL13 is a key molecule in autoimmune myasthenia gravis. Blood. 2006;108(2):432-440.

24. Weiss JM, Robinet M, Aricha R, et al. Novel CXCL13 transgenic mouse: inflammation drives pathogenic effect of CXCL13 in experimental myasthenia gravis. Oncotarget. 2016;7(7):7550-7562.

25. Zhang M, Zhou Y, Guo J, et al. Thymic TFH cells involved in the pathogenesis of myasthenia gravis with thymoma. Exp Neurol. 2014;254:200-205.

26. Song $\mathrm{Y}$, Zhou L, Miao F, et al. Increased frequency of thymic $\mathrm{T}$ follicular helper cells in myasthenia gravis patients with thymoma. J Thorac Dis. 2016;8(3):314-322.

27. Feng X, Wang D, Chen J, et al. Inhibition of aberrant circulating Tfh cell proportions by corticosteroids in patients with systemic lupus erythematosus. PLoS One. 2012; 7(12):e51982.

28. Arnold CN, Campbell DJ, Lipp M, Butcher EC. The germinal center response is impaired in the absence of T cell-expressed CXCR5. Eur J Immunol. 2007;37(1): 100-109. 


\title{
Neurology \\ Neuroimmunology \& Neuroinflammation
}

\author{
Intrathymic Plasmablasts Are Affected in Patients With Myasthenia Gravis With \\ Active Disease \\ Yohei Yamamoto, Naoko Matsui, Akiyuki Uzawa, et al. \\ Neurol Neuroimmunol Neuroinflamm 2021;8; \\ DOI 10.1212/NXI.0000000000001087
}

This information is current as of September 24, 2021

Updated Information \&

Services

References

Subspecialty Collections

Permissions \& Licensing

Reprints including high resolution figures, can be found at:

http://nn.neurology.org/content/8/6/e1087.full.html

This article cites 28 articles, 6 of which you can access for free at: http://nn.neurology.org/content/8/6/e1087.full.html\#\#ref-list-1

This article, along with others on similar topics, appears in the following collection(s):

All Immunology

http://nn.neurology.org//cgi/collection/all_immunology

All Neuromuscular Disease

http://nn.neurology.org//cgi/collection/all_neuromuscular_disease

Autoimmune diseases

http://nn.neurology.org//cgi/collection/autoimmune_diseases

Myasthenia

http://nn.neurology.org//cgi/collection/myasthenia

Information about reproducing this article in parts (figures,tables) or in its entirety can be found online at:

http://nn.neurology.org/misc/about.xhtml\#permissions

Information about ordering reprints can be found online:

http://nn.neurology.org/misc/addir.xhtml\#reprintsus

Neurol Neuroimmunol Neuroinflamm is an official journal of the American Academy of Neurology.

Published since April 2014, it is an open-access, online-only, continuous publication journal. Copyright

Copyright (C) 2021 The Author(s). Published by Wolters Kluwer Health, Inc. on behalf of the American

Academy of Neurology.. All rights reserved. Online ISSN: 2332-7812.

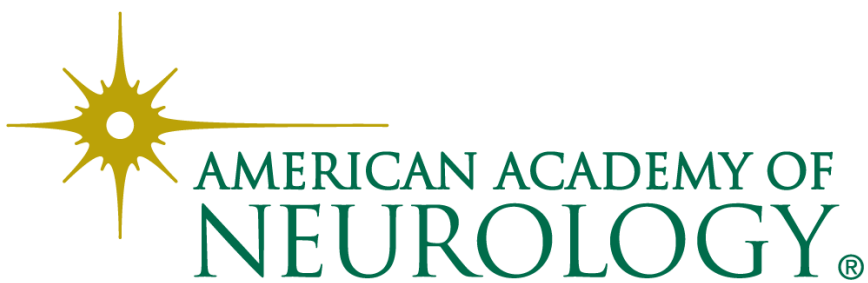

